\title{
Refleksi Pemimpin Yang Memberdayakan Berdasarkan Keluaran 18:18-24
}

\author{
Hergyana Saras Ningtyas \\ Sekolah Tinggi Agama Kristen Terpadu Pesat Salatiga \\ e-mail: hergy.ningtyas@gmail.com \\ Sriyati \\ STAK Terpadu Pesat Salatiga \\ e-mail:sriyatigamba@gmail.com
}

\begin{abstract}
The focus of leadership is not about position. An important leadership role is to help those being led to grow in Jesus Christ. This study discusses the Reflections of Empowering Leaders Based on Exodus 18: 18-24. The objective is to identify the role of leaders in the empowering principles studied from Exodus 18: 18-24 regarding the leadership of Moses. One of the reasons for Moses' leadership to be ineffective was that Moses was leading alone. Therefore Jethro, who was Musa's father-in-law as well as a priest in Midian known as a prophet, suggested that Moses develop the principle of empowering capable people to become leaders for the smaller groups under his leadership. The methodology used is literature research using primary sources from books, journals, and previous research as a source of study. The primary data is then analyzed and synthesized to become the novelty discussed in this study. So the orientation in empowering leadership is an effort to help the individual being led reach a better stage so that it is more light than Musa's single leadership. The leadership principles discussed include delegating leadership, increasing responsibility, increasing capacity, training independence, and being willing to learn and be taught. Thus, this leadership can have a wider influence and create empowered individuals, independent of certain situations or organizations. Today's leadership succession requires to form leaders who excel in the face of competition, innovation, and leadership succession skills that can be manifested in empowering leadership. An empowering leader is a solution to leadership problems in the Indonesian nation, the church, and the family as the smallest unit in the organization.
\end{abstract}

Keywords: Leader Reflection, Christian Leadership, Leadership Management, Empowering Principles, Leadership Succession, Exodus 18, Musa, Jethro. 


\begin{abstract}
Abstrak: Fokus kepemimpinan bukan tentang jabatan. Satu tugas penting dalam kepemimpinan adalah membantu orang yang dipimpin untuk bertumbuh di dalam Yesus Kristus. Penelitian ini membahas Refleksi Pemimpin Yang Memberdayakan Berdasarkan Keluaran 18:18-24. Tujuannya untuk mengidentifikasi peran pemimpin dalam prinsip memberdayakan yang dikaji dari Keluaran 18:18-24 tentang kepemimpinan Musa. Salah satu penyebab kepemimpinan Musa menjadi tidak efektif adalah kerena Musa memimpin sendirian. Oleh sebab itu Yitro yang merupakan mertua Musa sekaligus imam di Midian yang dikenal sebagai nabi menyarankan agar Musa mengembangkan prinsip memberdayakan orang-orang yang cakap untuk menjadi pemimpin-pemimpin untuk kelompok-kelompok yang lebih kecil di bawah pimpinannya. Metodologi yang digunakan adalah penelitian literatur dengan menggunakan sumber primer dari buku-buku, jurnal serta penelitian yang terdahulu sebagai sumber kajian. Data primer tersebut kemudian dianalisis dan disintensis untuk menjadi kebaharuan yang dibahas dalam penelitian ini. Jadi orientasi dalam kepemimpinan yang memberdayakan adalah upaya untuk menolong individu yang dipimpin mencapai tahapan yang lebih baik sehingga lebih meringankan dibanding dengan kepemimpinan tunggal Musa. Prinsip kepemimpinan yang dibahas meliputi mendelegasikan kepemimpinan, meningkatkan tanggung jawab, meningkatkan kapasitas, melatih kemandirian serta mau belajar dan diajar. Dengan demikian, kepemimpinan tersebut dapat membawa pengaruh yang lebih luas dan menciptakan individu yang berdaya, tidak bergantung pada situasi ataupun organisasi tertentu. Suksesi kepemimpinan masa kini membutuhkan untuk membentuk pemimpin yang unggul menghadapi kompetisi, inovasi, serta kemampuan suksesi kepemimpinan yang dapat diwujudkan dalam kepemimpinan memberdayakan. Pemimpin yang memberdayakan merupakan solusi atas permasalahan kepemimpinan di bangsa Indonesia, gereja dan keluarga sebagai unit terkecil dalam organisasi
\end{abstract}

Kata Kunci: Refleksi Pemimpin, Kepemimpinan Kristen, Manajemen Kepemimpinan, Prinsip Memberdayakan, Suksesi Kepemimpinan, Kitab Keluaran 18, Musa, Yitro.

\title{
PENDAHULUAN
}

Sonny Zaluchu mengutip pernyataan J Oswal Sanders menyatakan bahwa tanpa pengaruh, seseorang tidak akan mampu memimpin orang lain. ${ }^{1}$ Dengan demikian dapat dipahami bahwa kepemimpinan harus memiliki pengaruh. J. Adair berpendapat kepemimpinan merupakan seni memengaruhi sekelompok orang untuk mengikuti rangkaian kegiatan, tentang bagaimana mengendalikan, mengarahkan dan membuat orang yang dipimpin mengeluarkan potensi terbaik. ${ }^{2}$ Senada dengan hal tersebut, Myles Munroe dalam tulisannya yang dikutip oleh Elkana Chrisna Wijaya, menyatakan bahwa tantangan terbesar yang dihadapi kepemimpinan di masa kini, bukanlah mengenai

\footnotetext{
${ }^{1}$ Sonny Zaluchu, "Respons Tests of Leadership Menurut Teori Frank Damazio Pada Mahasiswa Pascasarjana Jurusan Kepemimpinan Kristen STT Harvest Semarang," Jurnal Jaffray 16, no. 2 (2018): 145.

${ }^{2}$ John Adair, Cara Menumbuhkan Pemimpin (Gramedia Pustaka Utama, 2007).
} 
kurangnya dana, program-program sosial, atau bahkan pemerintahan yang baru, melainkan kekosongan posisi kepemimpinan. Kebutuhan utama di seluruh dunia saat ini adalah kepemimpinan yang berkualitas, bermoral, berdisiplin, dan berpusat pada prinsip. ${ }^{3}$ Hal tersebut juga disampaikan oleh John C. Maxwell, dalam teori 5 Level Leadership bahwa pemimpin pada level tertinggi (level 5) adalah pemimpin yang berfokus memberdayakan orang lain dan melibatkannya dalam kepemimpinan mereka sehingga dapat mendongkrak kepemimpinan semua orang yang dipimpin. ${ }^{4}$ Dale Carnegie mendukung pernyataan tersebut dengan mengemukakan bahwa hal yang tidak kalah penting dari sensitivitas adalah kemauan untuk menantang orang dengan harapan dan tanggung jawab. ${ }^{5}$ Selain itu, untuk istilah memberdayakan, Steven Covey berkata mewujudkan sinergi adalah seperti mencari pilihan ketiga dari dua pilihan agar dapat memberdayakan hingga mencapai hasil lebih. ${ }^{6}$ Hal serupa juga dikatakan oleh Ahmad Tabrani, bahwa tugas pemimpin adalah membuat perubahan menuju kondisi yang lebih baik. ${ }^{7}$ Berdasarkan beberapa pendapat di atas dapat disimpulkan bahwa seorang pemimpin harus memberdayakan individu yang dipimpin untuk mencapai hasil lebih baik serta mengangkat kepemimpinannya. Potensi yang dimiliki harus diupayakan mencapai puncak. Pemimpin masa kini harus memiliki kemampuan untuk melatih serta membantu yang dipimpin agar mencapai keadaan lebih baik dan mandiri sehingga menjadi individu yang berdaya.

Kajian Alkitab juga menekankan hal yang sama. Tokoh Musa, seorang pemimpin besar dan terkenal zaman Perjanjian Lama juga menerapkan prinsip serupa (Kel.18:18-24). Saat Musa memimpin, seluruh rakyat membawa perkaranya kepada Musa untuk diberi petunjuk dari Allah. Bangsa Israel berdiri dari pagi hingga petang untuk mendengar petunjuk dari Allah melalui Musa, pemimpin yang dipilih Allah (Kel.18:13). Musa memimpin sendirian, dan tidak memberdayakan orang lain dalam kepemimpinannya sehingga tidak maksimal. Kemudian Yitro, mertuanya yang juga merupakan seorang imam mengkritik kepemimpinan Musa. Memberi saran agar Musa

\footnotetext{
${ }^{3}$ Elkana Chrisna Wijaya, "Prinsip Kepemimpinan Yang Efektif Menurut Kitab Keluaran 18:13-27," Harvester: Jurnal Teologi dan Kepemimpinan Kristen 6, no. 3 (2017): 120-140.

${ }^{4}$ John C Maxwell, The 5 Level Leadership (Surabaya: MIC, 2017), 306.

${ }^{5}$ Dale Carnegie, Leadership Mastery, 9th ed. (Jakarta, 2019), 205.

6 Stephen R Covey, The 7 Habits of Highly Effective People, ed. Lyndon Saputra (Tangerang Selatan: Binarupa Aksara, n.d.), 300.

7 Ahmad Tabrani, "PENGARUH KEPEMIMPINAN DAN MENTORING TERHADAP MOTIVASI DALAM MELAYANI," EDULEAD: Journal of Christian Education and Leadership 1, no. 1 (June 9, 2020): 77-91, http://stak-pesat.ac.id/e-journal/index.php/edulead/article/view/23.
} 
dapat memberdayakan orang-orang yang cakap di sekitarnya. Itulah konsep kepemimpinan, membawa orang lain mencapai level tertinggi dari kepemimpinan untuk memimpin secara bersama-sama. ${ }^{8}$ Jika tugas kepemimpinan dapat didelegasikan secara tepat, maka kepemimpinan akan berjalan lebih efektif dan efisien. ${ }^{9}$

Fakta tentang perubahan tatanan sosial masa kini juga memerlukan gagasan baru untuk berkarya dan mencapai titik keberhasilan yang diharapkan. ${ }^{10}$ Dengan demikian manusia akan menjadi pribadi yang berdaya karena mampu menciptakan keberhasilan melalui ide atau gagasan yang dimiliki. Kemampuan menemukan gagasan dalam pemikiran individu identik dengan kemandirian yang tercipta sebagai hasil proses perubahan sosial yang erat kaitannya dengan kepemimpinan. Pemerintah yang dipercaya oleh rakyat untuk menciptakan perubahan juga tidak sepenuhnya menjadi jaminan. Data tindak pidana korupsi berdasarkan profesi/jabatan yang dilaporkan dalam website KPK mencatat sebanyak 110 kasus tindak korupsi yang terjadi di tahun 2020. Berdasarkan data tersebut dicatat 43 dari 110 kasus dilakukan oleh anggota DPR dan DPRD, walikota/bupati dan wakil bupati serta Eselon I, II dan III. ${ }^{11}$ Dari fakta di atas dapat dikaji bahwa kepemimpinan perlu mengalami terobosan yang baru, salah satunya adalah dengan kepemimpinan yang memberdayakan.

Teori-teori, kajian Alkitab dalam kisah Musa dan fakta yang terjadi juga menjadi bukti bahwa kepemimpinan perlu dikaji lebih jauh. Oleh sebab itu, berdasarkan ketiga penjelasan di atas maka penulis melakukan penelitian terhadap prinsip kepemimpinan yang memberdayakan dengan tujuan untuk mengidentifikasi peran pemimpin dalam prinsip memberdayakan yang dikaji dari Kel. 18:18-24. Sehingga fungsi kepemimpinan dapat menjadi lebih efektif dan seturut Firman Allah sebagai landasan.

\section{METODE PENELITIAN}

Metode penelitian yang digunakan dalam penelitian ini adalah penelitian literatur dengan mengumpulkan sumber-sumber primer dari buku-buku, dan penelitian

\footnotetext{
${ }^{8}$ Maxwell, The 5 Level Leadership.

${ }^{9}$ Robert M Paterson, Kitab Kel. (Jakarta: BPK Gunung Mulia, 2006), 245.

${ }^{10}$ Indradin Indradin and Irawan Irawan, Strategi Dan Perubahan Sosial (Yogyakarta: CV BUDI UTAMA, 2016), 19.

${ }^{11}$ Komisi Pemberantasan Korupsi, "Statistik TPK Berdasarkan Profesi/Jabatan," Kpk.Go.Id, last modified 2021, https://www.kpk.go.id/id/statistik/penindakan/tpk-berdasarkan-profesi-jabatan.
} 
sebelumnya. ${ }^{12}$ Proses telaah alkitab dan teori-teori pendukung sebagai bahan kajian dilakukan dengan mencari informasi, mengambil informasi, mengevaluasi, memeriksa, menganalisis dan mensintesa. ${ }^{13}$ Data-data yang sudah diperoleh peneliti kemudian dijelaskan secara deskriptif ${ }^{14}$ dan dianalisa untuk mendalami prinsip kepemimpinan yang memberdayakan berdasarkan kitab Keluaran 18:18-24 sehingga menjadi sebuah kajian baru dalam penelitian.

\section{PEMBAHASAN DAN HASIL}

\section{Kepemimpinan Musa}

Kisah dalam perikop Yitro mengunjungi Musa yang tertulis di kitab Kel. 18:127 menjelaskan kepemimpinan Musa sebelum masa pengangkatan hakim-hakim. Saat mengemban tugas sebagai pemimpin, pada saat itu Musa sebagai pemimpin pada zamannya adalah perantara antara Allah dan umat-Nya sekaligus hakim dan orang yang mengadili seluruh rakyat. ${ }^{15}$ Musa menjadi satu-satunya penyampaian pesan Allah kepada setiap perkara yang disampaikan oleh bangsa Israel. Dengan demikian, kepemimpinannya menjadi tidak efektif karena bangsa itu sangat banyak dan hanya Musa sendiri yang dapat mengadili semua perkara yang terjadi, tidak ada satu orangpun yang membantu dalam kepemimpinan Musa. Tugas dan tanggung jawab kepemimpinan menjadi berat jika dilakukan sendirian. Melihat situasi kepemimpinan Musa yang tidak efektif, Yitro (mertua Musa) datang mengunjungi Musa serta memberi kritik dan saran untuk masalah kepemimpinan Musa. Yitro menyampaikan dengan strategi kepemimpinan yang dijalankan oleh Musa sebagai pemimpin tunggal akan membuat Musa mengalami kelelahan (Kel. 18:18), sebagaimana yang diungkapkan oleh Chrisna Wijaya bahwa Yitro menyaksikan metode Musa dalam memimpin dan mengadili bangsa Israel, kemudian memberikan evaluasi dan memberikan nasihat yang positif dengan tujuan untuk mendatangkan keefektifan bagi kepemimpian Musa, bagi bangsa Israel dan bagi rencana Allah sendiri. ${ }^{16}$ Saran tersebut dipandang baik oleh Musa dan

12 Sonny Eli Zaluchu, "Strategi Penelitian Kualitatif Dan Kuantitatif Di Dalam Penelitian Agama," Evangelikal: Jurnal Teologi Injili dan Pembinaan Warga Jemaat 4, no. 1 (January 31, 2020): 28, https://journal.sttsimpson.ac.id/index.php/EJTI/article/view/167.

${ }^{13}$ Mahyuddin K M Nasution, "Penelaahan Literatur," Teknik Penulisan Karya Ilmiah 3 (2017).

${ }^{14}$ Amir Hamzah, Metode Penelitian Kepustakaan Library Research (Malang: Literasi Nusantara, 2020), 6.

${ }^{15}$ W.R.F Browning, Kamus Alkitab (Jakarta: BPK Gunung Mulia, 2009), 278.

${ }^{16}$ Wijaya, "Prinsip Kepemimpinan Yang Efektif Menurut Kitab Keluaran 18:13-27." 
oleh sebab itu Musa memilih menerima nasihat Yitro untuk mencari pemimpinpemimpin dalam kelompok-kelompok yang lebih kecil agar tugas kepemimpinannya menjadi lebih ringan. ${ }^{17}$ Dengan demikian, tidak semua perkara diadili oleh Musa. Musa memilih mengangkat kepala pasukan seribu, seratus, lima puluh dan sepuluh orang (Kel.18:21) untuk membantu Musa dalam menjalankan tugas kepemimpinan. Hanya perkara yang besar dan sukar yang diperhadapkan kepada Musa, sedangkan perkaraperkara kecil dapat diadili oleh pemimpin-pemimpin kelompok-kelompok yang lebih kecil (Kel. 18.22). Dengan demikian Musa dapat memberdayakan orang lain serta tidak kelelahan karena harus mengadili semua perkara yang terjadi pada bangsa tersebut sendirian.

Jika perikop ini dibaca secara runtut, Kel. 18:20 menjelaskan bahwa sebelum Musa mengangkat pemimpin-pemimpin untuk kelompok yang lebih kecil, Musa harus mengajarkan ketetapan-ketetapan, keputusan-keputusan, jalan yang harus dilalui serta pekerjaan yang harus dilakukan kepada pemimpin-pemimpin yang akan ditunjuk. Hal ini berbicara tentang pendelegasian tugas, melatih dan memberikan kepercayaan kepada orang yang sedang dipimpin. Musa tidak berhenti dari kepemimpinannya. Sembari mengerjakan tugas kepemimpinan, Musa juga melatih pemimpin kelompok-kelompok kecil untuk mencapai puncak kepemimpinan. Seorang pemimpin perlu menolong untuk memberdayakan orang-orang yang dipimpin. ${ }^{18}$ Memanajemen sumber daya yang ada sehingga menjadikan kepemimpinan lebih efektif. ${ }^{19}$ Inilah alasan mengapa Yitro memberi kritik serta nasihat kepada Musa untuk mengangkat pemimpin-pemimpin dalam kelompok-kelompok lebih kecil dalam kepemimpinannya. Hasilnya terbukti pada Kel. 18:25 bahwa dari antara bangsa tersebut ternyata terdapat orang-orang yang cakap yang dapat dipilih menjadi pemimpin-pemimpin untuk kelompok-kelompok yang lebih kecil.

Dalam memberdayakan pemimpin, hal yang perlu ditekankan adalah tentang mengajarkan ketetapan-ketetapan Allah. Proses mengajarkan ketetapan-ketetapan Allah akan membuat orang yang ditunjuk sebagai pemimpin untuk menaikkan kapasitas serta

\footnotetext{
${ }^{17}$ Paterson, Tafsiran Alkitab Kitab Keluaran.

${ }^{18}$ Wisnu Prabowo, "Peran Elkana Dan Hana Terhadap Masa Kecil Samuel: Tahap Awal Mencetak Pemimpin Kristen," EDULEAD: Journal of Christian Education and Leadership 1, no. 2 (December 10, 2020): 162-179, http://stak-pesat.ac.id/e-journal/index.php/edulead/article/view/39.

${ }^{19}$ K Katarina and Krido Siswanto, "Keteladanan Kepemimpinan Yesus Dan Implikasinya Bagi Kepemimpinan Gereja Pada Masa Kini," Evangelikal: Jurnal Teologi Injili dan Pembinaan Warga Jemaat 2, no. 2 (2018): 87-98.
} 
tanggung jawab dalam memimpin sesuai dengan ketetapan-ketetapan Allah. Tugas penting seorang pemimpin adalah untuk memberdayakan. Apapun yang dikerjakan ditujukan membantu orang yang dipimpin untuk bertumbuh menjadi individu yang lebih efektif.

\section{Pemimpin yang Memberdayakan}

Pemberdayaan merupakan keadaan sosial, sikap dan perilaku yang diubah ke arah positif dan kreatif serta mendorong seseorang untuk lebih mandiri sehingga menjadi orang yang berdaya. ${ }^{20}$ Arti lain memberdayakan merupakan upaya untuk meningkatkan kemampuan individu dalam pengetahuan dan keahlian. ${ }^{21}$ Jika demikian, dalam prinsip memberdayakan indikator yang harus ada adalah perubahan dari sikap pribadi yang bergantung pada orang lain menuju pribadi yang lebih mandiri.

Penelitian Gideon memaparkan fakta bahwa Musa merupakan pemimpin yang baik, namun tidak memberdayakan orang yang dipimpin sehingga Musa menjadi satusatunya pusat komunitas sehingga mengakibatkan pengikutnya tidak berkembang secara maksimal. ${ }^{22}$ Menindak lanjuti hal tersebut penelitian Amos Hosea juga memaparkan bentuk aplikasi kisah Yitro dan Musa dalam gereja adalah adanya kelompok sel. ${ }^{23}$ Tanpa kelompok kecil, kepemimpinan menjadi tidak efektif. ${ }^{24}$ Dalam kelompok kecil, jabatan pemimpin dapat menunjang untuk meningkatkan kapasitas dan tanggung jawab. Selain memberi pengetahuan, memberdayakan juga berarti memberi kekuasaan atau memberi otoritas kepada orang lain. ${ }^{25}$ Artinya, dengan otoritas sebagai pemimpin, orang yang sedang diberdayakan akan melatih kemampuan mereka dengan tugas-tugas atau tanggung jawab yang diemban. Jadi tidak ada pihak yang merasa dirugikan. Jika ditarik kembali pada kisah Musa, baik Musa juga pemimpin-pemimpin kelompok kecil yang

\footnotetext{
20 Edi Suharto, Membangun Masyarakat Memberdayakan Rakyat Kajian Strategis Pembangunan Kesejahteraan Sosial Dan Pekerjaan Sosial (Bandung: PT Refika Aditama, 2009), 60.

${ }^{21}$ Abdurrohman Irwan, ed., Membangun Dan Memberdayakan Potensi Di Masyarakat Di Kala Pandemi (Bandung: LP2M UIN Sunan Gunung Djati Bandung, 2021), 78.

22 Gidion Gidion, "EFEKTIFITAS KEPEMIMPINAN YANG MEMBERDAYAKAN DALAM MENINGKATKAN PERTUMBUHAN GEREJA DI GEREJA JEMAAT KRISTEN INDONESIA MARANATHA UNGARAN," Shift Key: Jurnal Teologi dan Pelayanan 8, no. 1 (2018).

23 Amos Hosea, "FENOMENA KELOMPOK SEL (CELL GROUP) DALAM GEREJA LOKAL," Diegesis: Jurnal Teologi 3, no. 2 (2018): 1-11.

${ }^{24}$ Imron Widjaja, "PERKEMBANGAN KOMSEL PELAJAR DALAM PERTUMBUHAN ROHANI JEMAAT GBI GRAHA PENA JAKARTA," The Way Jurnal Teologi dan Kependidikan 5, no. 2 (2019): 88-100.

${ }^{25}$ Irwan, Membangun Dan Memberdayakan Potensi Di Masyarakat Di Kala Pandemi.
} 
telah dipilih sama-sama merasa diuntungkan. Musa menjadi tidak kelelahan karena harus menjadi hakim dan pemimpin sendirian untuk semua rakyat, sedangkan pemimpin-pemimpin kelompok kecil dapat menambah kapasitas melalui mengadili perkara-perkara yang terjadi dalam kelompok masing-masing. Bahkan bangsa yang dipimpin juga menjadi senang kerena lebih efektif. Menurut definisi yang telah dipaparkan, berikut adalah prinsip yang dipakai dalam kepemimpinan yang memberdayakan.

\section{Mendelegasikan Kepemimpinan}

De Jong dalam Ancok mengemukakan salah satu sikap pemimpin yang membawa transformasi dalam hal inovasi adalah mendelegasikan kepemimpinan. ${ }^{26}$ Didukung oleh penelitian Minsih dkk menjelaskan salah satu faktor penunjang meningkatnya mutu sekolah dari kepemimpinan adalah tentang mengelola organisasi, di dalamnya termasuk dengan mendelegasikan tugas kepemimpinan. Kemajuan ini meningkat menjadi $75 \% .{ }^{27}$ Penelitian kuantitatif Siswanto dkk juga mengemukakan gaya kepemimpinan delegasi sangat berpengaruh dalam kinerja karyawan. ${ }^{28}$ Artinya dengan mendelegasikan kepemimpinan dapat membawa transformasi ke arah yang lebih baik bagi organisasi juga bagi individu yang dipimpin.

Tanpa ada pendelegasian pemimpin yang diberikan oleh Musa, pemimpinpemimpin kelompok kecil tersebut tidak akan dapat berkembang dalam menjalankan tugas kepemimpinannya. Dengan demikian kepemimpinan tidak akan mencapai kualitas maksimal yang lebih baik dan efisien.

Pendelegasian kepemimpinan tidak perlu menunggu pemimpin sebelumnya meninggal atau sakit dan atau sebab yang lain seperti dalam konteks pada nats topik di atas bahwa Musa diminta Yitro untuk memilih orang orang yang cakap untuk bersamasama memimpin bangsa Israel. Kepemimpinan dapat dilakukan secara bersama-sama meskipun dengan tingkatan usia yang berbeda. Hal tersebut dinamakan kepemimpinan

26 Djamaludin Ancok, Psikologi Kepemimpinan Dan Inovasi (Jakarta: Gelora Aksara Pratama, 2012).

${ }^{27}$ Minsih Minsih, Rusnilawati Rusnilawati, and Imam Mujahid, "Kepemimpinan Kepala Sekolah Dalam Membangun Sekolah Berkualitas Di Sekolah Dasar," Profesi Pendidikan Dasar 6, no. 1 (2019): 29-40.

${ }^{28}$ Rendyka Dio Siswanto and Djambur Hamid, "Pengaruh Gaya Kepemimpinan Terhadap Kinerja Karyawan (Studi Pada Karyawan Divisi Human Resources Management Compensation and Benefits PT Freeport Indonesia),” Jurnal Administrasi Bisnis 42, no. 1 (2017): 189-198. 
intergenerasinoal, sepaham yang dituliskan oleh Lintang dalam tesis yang mengutip dari Peter Menconi bahwa gereja intergenerasional adalah gereja yang terbuka untuk semua generasi, masing masing generasi yang berbeda tidak hanya berbagi ruang namun berjalan dengan berbagi pengalaman hidup bersama. ${ }^{29}$ Dengan demikian ditambahkan bahwa kepemimpinan intergenerasional bukan hanya untuk satu generasi tetapi secara menyeluruh. Maka Musa yang sudah memiliki banyak pengalaman memberi kesempatan para pemimpin yang lain untuk memimpin bersama, dengan rentan usia yang berbeda. Ini adalah bagian Musa dalam mewujudkan prinsip memberdayakan dalam kepemimpinan.

\section{Meningkatkan Tanggung Jawab (Kel.18:21a)}

Indikator pertama yang dibahas untuk mewujudkan prinsip memberdayakan adalah meningkatkan tanggung jawab.

"Pada Keluaran 18:21a (TB) tertulis Di samping itu kaucarilah dari seluruh bangs aitu orang-orang yang cakap dan takut akan Allah, orang -orang yang dapat dipercaya, dan yang benci kepada pengejaran suap;"

Kata "dapat dipercaya" pada ayat ini merujuk pada indikator tanggung jawab sebagai pemimpin. Proses kepemimpinan juga tidak luput dari melatih tanggung jawab orang yang sedang dipimpin atau bahkan pemimpin tersebut. Tangung jawab yang dikerjakan dapat berupa membuat keputusan yang berdampak bagi lingkungan sekitar. ${ }^{30}$ Hengki Wijaya juga memaparkan secara spesifik bahwa tanggung jawab diartikan sebagai kewajiban intelektual dan moral untuk memperbaiki kesalahan, memenuhi kewajiban, komitmen serta mampu menanggung tekanan. ${ }^{31}$ Musa sebagai pemimpin berusaha keras untuk melatih tanggung jawab bagi pemimpin-pemimpin kelompok kecil. Proses melatih tanggung jawab dimulai dari saat Musa memilih pemimpinpemimpin kelompok kecil dan mendelegasikan kepemimpinan (Kel.18:21). Pemimpinpemimpin terpilih sudah lebih dahulu diajarkan hal-hal yang dibutuhkan untuk mengemban tugas kepemimpinan yang akan diberikan. Mulai dari ketetapan-ketetapan,

\footnotetext{
29 LINTANG ANGGRAENI, "GEREJA KRISTEN JAWA PURWOREJO MENJADI GEREJA INTERGENERASIONAL” (UKDW, 2020).

${ }^{30}$ M.Chazienul Ulum, Perilaku Organisasi Menuju Orientasi Pemberdayaan (Malang: UB Press, 2016), 77.

31 Hengki Wijaya, "Keunggulan Integritas Generasi Muda Dalam Mewujudkan Kepemimpinan Rohani Yang Bertanggungjawab," Online] https://www. researchgate. net/profile/Hengki_Wijaya3 (2015).
} 
keputusan-keputusan, menunjukkan jalan yang harus dilalui dan pekerjaan yang akan dilakukan (Kel. 18:20). Dengan kata lain, sebelum melatih tanggung jawab kepemimpinan, ada proses bimbingan yang dilakukan Musa sehingga pada akhirnya dengan setiap tugas yang diberikan, ada tanggung jawab yang berjalan beriringan. Pembimbingan yang dilakukan sangat berguna untuk menolong pemimpin-pemimpin kelompok kecil dalam mengambil keputusan-keputusan yang tepat dalam kepemimpinan. Konflik yang ada akan membantu pemimpin-pemimpin kelompok kecil untuk meningkatkan kapasitas $^{32}$ serta tanggung jawab.

\section{Meningkatkan Kapasitas (Kel.18:22)}

Kata meningkatkan kapasitas dalam penelitian ini dirujuk dari kata perkara yang diadili oleh pemimpin pada teks Kel.18:22.

"Dan sewaktu-waktu mereka harus mengadili di antara bangsa; maka segala perkara yang besar haruslah dihapapkan mereka kepadamu, tetapi segala perkara yang kecil diadili mereka sendiri; dengan demikian mereka meringankan pekerjaanmu, dan mereka bersama-sama dengan engkau turut menanggungnya." (TB)

Pemimpin tidak hanya bertanggung jawab menunjukkan arah yang benar kepada pengikutnya, melainkan juga memberdayakan pengikutnya untuk melakukan tugas yang diberikan. ${ }^{33}$ Dengan demikian, dalam kepemimpinan harus ada peningkatan kapasitas pemimpin untuk menyelesaikan tugas-tugas dan tanggung jawab yang diberikan oleh pemimpin di atasnya. Penelitian Febby Lidya mengungkapkan mengelola dan mengembangkan kelompok dapat meningkatkan kualitas mengelola pekerjaan serta kapasitas pribadi. ${ }^{34}$ Pemberian tugas dengan tingkat kesulitan tertentu secara tidak langsung dapat mengembangkan kapasitas. Pendapat ini juga terbukti dalam ranah pendidikan seperti yang dipaparkan oleh Ni Made Nita Risati bahwa pemberian tugas dapat meningkatkan perkembangan pada anak. ${ }^{35}$ Peningkatan kapasitas yang diperoleh dalam kepemimpinan tersebut terjadi karena adanya proses yang melatih untuk berpikir,

\footnotetext{
${ }^{32}$ Ulum, Perilaku Organisasi Menuju Orientasi Pemberdayaan.

${ }^{33}$ Kenneth Boa, Sid Buzzell, and Bill Perkins, Kepemimpinan Ilahi Dalam Rupa Insani (Jakarta: Yayasan Komunikasi Bina Kasih, 2013), 186.

${ }^{34}$ Febby Lidya, "Peran Pemimpin Dalam Peningkatan Kapasitas Kelompok Berbasis Community Based Tourism" (2018).

35 Ni Made Nita Risanti, "Penerapan Metode Pemberian Tugas Berbantuan Media Konkrit Melalui Kegiatan Finger Painting Untuk Meningkatkan Perkembangan Sosial Emosional," Jurnal Pendidikan Anak Usia Dini Undiksha 1, no. 1 (2013).
} 
menganalisa dan menanggapi permasalahan sehingga menemukan solusi yang paling tepat.

Prinsip tersebut juga dilakukan oleh Musa saat memilih pemimpin-pemimpin untuk kelompok-kelompok yang lebih kecil dengan tugas mengadili perkara. Perkaraperkara yang dihadapkan kepada pemimpin dalam kelompok-kelompok kecil dapat menjadi latihan yang berguna untuk menambah kapasitas untuk menemukan solusi sehingga dapat melaksanakan tugas kepemimpinan dalam kelompok yang lebih kecil. Mengadili perkara-perkara sampai mendapat solusi serta meningkatkan kapasitas.

\section{Melatih Kemandirian (Kel.18:21b)}

Memberdayakan individu merupakan proses membangun pola pikir terhadap dirinya sendiri untuk mencapai pengembangan yang menjadikannya lebih mandiri. ${ }^{36}$ Hasil penelitian jurnal di ranah pendidikan milik Dina Octaria Putri Fitriasari dan Novita Sari memaparkan diskusi kelompok, serta pemberian tugas dapat meningkatkan kemandirian. ${ }^{37}$ Prinsip dalam tahapan ini membantu membentuk indivdu menjadi yang lebih berdaya, melalui tanggung jawab kepemimpinannya. Selanjutnya akan menjadi pribadi yang tidak lagi terikat atau bergantung pada situasi dan kondisi tertentu. Proses melatih kemandirian yang dilakukan Musa dalam Kel.18:21b sebagai berikut.

"tempatkanlah mereka di antara bangs aitu menjadi pemimpin seribu orang, pemimpin seratus orang, pemimpin lima puluh orang dan pemimpin sepuluh orang" (TB)

Cara Musa memilih pemimpin untuk mengadili perkara bangsa dapat memberikan akses kepada pemimpin untuk saling diskusi dalam penyelesaian konfik kepemimpinan agar mencapai kemandirian dalam kelompok kecil meskipun perkaraperkara yang sulit masih diperhadapkan kepada Musa. Memahami persoalan-persoalan yang sulit dan menyelesaikannya dalam kelompok pasukan akan melatih pemimpin menjadi pribadi yang lebih mandiri. ${ }^{38}$

\section{Mau Belajar dan Diajar (Kel.18:24)}

\footnotetext{
${ }^{36}$ Herning Suryo, "Pemberdayaan Masyarakat Dalam Pengembangan Kemandirian Masyarakat," Transformasi 1, no. 29 (2017).

37 Dina Octaria, Putri Fitriasari, and Novita Sari, "Blended Learning Dengan Macromedia Flash Untuk Melatih Kemandirian Belajar Mahasiswa," Jurnal Elemen 6, no. 1 (2020): 25-38.

38 Ibid.
} 
Prinsip mau belajar dan diajar dilakukan oleh Musa. Kerendahan hati Musa dapat dilihat saat mendengar nasihat dari Yitro, mertuanya yang adalah seorang imam di Midian dan juga dikenal sebagai seorang nabi ${ }^{39}$ untuk memilih para pemimpin guna menangani atau memimpin kelompok-kelompok yang lebih kecil di bawah kepemimpinan Musa.

Kel. 18:24 mencatat "Musa mendengarkan perkataan mertuanya itu dan dilakukannyalah segala yang dikatakannya" (TB)

Cara Musa merespon nasihat Yitro, mertuanya menunjukkan bahwa Musa adalah seorang pemimpin yang mau belajar dan bersedia diajar oleh Yitro walaupun Musa juga memiliki pengalaman memimpin. Meskipun demikian, mendengar dari pemimpin sebelumnya adalah hal terbaik. Adapun nasihat Yitro pada Kel.18:19 -21 meminta Musa untuk mencari orang orang yang takut akan Allah dan yang cakap, dalam hal ini orang orang tersebut merupakan orang yang dapat diajarkan ketetapan ketetapan sehingga pemimpin yang mau belajar dan diajar sangat penting untuk menjadi bagian dari pemimpin yang memberdayakan.

\section{Urgensi Prinsip Kepemimpinan Yang Memberdayakan}

Paparan tentang teladan kepemimpinan Musa dalam memberdayakan dapat menjadi teladan dalam mengemban tugas kepemimpinan. Prinsip memberdayakan sering diabaikan pada masa kini. Rekapitulasi data dari Komisi Pemberantasan Korupsi di ranah penindakan mencatat terdapat 497 kasus korupsi selama tahun 2020 yang terjadi di Indonesia. ${ }^{40}$ Jumlah ini juga mengalami peningkatan dari tahun sebelumnya yang hanya terdapat 380 kasus. ${ }^{41}$ Hal ini juga dapat menjadi tanda bahwa kepemimpinan di Indonesia tidak sepenuhnya berpusat pada pengikut, masih ada pemimpin yang berpusat pada dirinya sendiri. Agar tidak berpusat kepada pribadi, maka memberdayakan merupakan jawabannya.

\section{Unggul Menghadapi Kompetisi}

\footnotetext{
39 Sri Wahyuni Kusradi, "Pengenalan Akan Nama Allah Sebagai Peneguhan Iman Dalam Masa Kesesakan,” SCRIPTA: Jurnal Teologi dan Pelayanan Kontekstual 6, no. 2 (2018): 184-204.

${ }^{40}$ KPK, "Komisi Pemberantasan Korupsi," Kpk.Go.Id, last modified 2021, accessed April 5, 2021, https://www.kpk.go/id/statistik/penindakan/109-statistik.

41 Ibid.
} 
Kompetisi tidak hanya terjadi dalam dunia pendidikan. ${ }^{42}$ Usai Pendidikan formal juga manusia akan tetap diperhadapkan dengan kompetisi di bidang kerja. Sebagai pemimpin, perlu ada persiapan yang panjang untuk menghadapi kompetisi bebas yang terjadi saat ini. African Proverb mengemukakan if you want go fast, youcan go alone. If you want to go far, you can go together. ${ }^{43}$ Artinya jika kamu ingin pergi cepat, kamu bisa pergi sendiri. Jika Anda ingin pergi jauh, Anda bisa pergi bersama. Ketua komite IV Dewan Perwakilan Daerah (DPD) Elviana mengungungkapkan kompetensi Sumber Daya Manusia (SDM) adalah salah satu hal yang perlu ditingkatkan untuk menghadapi persaingan pasar global. ${ }^{44}$ Dunia kompetisi saat ini membutuhkan kompetensi dan kerja sama yang membawa kepemimpinan beranjak lebih jauh dan tahan uji. Oleh sebab itu untuk memberdayakan pemimpin perlu adanya kualitas unggul yang bukan hanya dimiliki oleh pemimpin tertinggi melainkan pemimpin-pemimpin kelompok kecil juga agar secara bersinergi mencapai kualitas unggul menghadapi kompetisi. Hal yang sama juga dilakukan Musa. Musa membimbing dan membantu pemimpin kelompok-kelompok kecil untuk mencapai keunggulan guna menghadapi kompetisi (Kel. 18:20) sehingga keberhasilan bangsa tidak hanya bergantung pada Musa seorang diri, malainkan bentuk kerja sama dengan pemimpin-pemimpin pada kelompok-kelompok kecil yang dilatih untuk menghadapi konflik nyata dalam masingmasing rakyat yang dipimpin. Keberhasilan-keberhasilan kecil yang tercipta dalam kelompok-kelompok di bawah pimpinan Musa saling bersinergi menciptakan kualitas unggul menghadapi kompetisi dalam kepemimpinan Musa.

\section{Kepemimpinan Memerlukan Inovasi}

Ernani Hidayati memaparkan dalam jurnal kewirausahaan bahwa skil inovatif berguna untuk memuaskan kebutuhan pelanggan. ${ }^{45}$ Kreativitas berhubungan erat dengan inovasi. Kreativitas dapat melahirkan inovasi. ${ }^{46}$ Kreativitas yang berupa ide atau

42 Indri Murniawaty and Wisudani Rahmaningtyas, "Kesiapan Mahasiswa Jurusan Pendidikan Adminstrasi Perkantoran Dalam Kompetisi Pasar Kerja Di Era Mea," PROMOSI: Jurnal Program Studi Pendidikan Ekonomi 5, no. 1 (2017).

${ }^{43}$ Pudijiarto Boestam, Smart Christian Leadership (Yogyakarta: ANDI OFFSET, 2013), 13.

44 Kompas Kompas, "Persaingan Produk Di Pasar Global," Kementerian Perindudtrian Republik Indonesia, last modified 2020, accessed April 5, 2021, https://kemenperin.go.id/artikel/21400/PersainganProduk-di-Pasar-Global.

45 Deden A Wahab Sya'roni and Janivita J Sudirham, “Kreativitas Dan Inovasi Penentu Kompetensi Pelaku Usaha Kecil," Jurnal Manajemen Teknologi 11, no. 01 (2012): 1-17.

${ }^{46}$ Sisca et al., Manajemen Inovasi, ed. Janner Simarmata (Yayasan Kita Menulis, 2021), 131. 
gagasan dapat memunculkan inovasi baru dalam kepemimpinan. Cara-cara lama tidak salah namun perlu dikaji relevansinya untuk masa kini. Tanpa ada inovasi saya membayangkan di dunia yang serba canggih ini kita akan tetap naik kuda atau unta sebagai alat transportasi. Bukankah itu menjadi hal yang aneh? Begitu pula dengan kepemimpinan. Kepemimpinan butuh inovasi. Para pemimpin bukan hanya dilahirkan, melainkan pemimpin juga dibentuk. ${ }^{47}$ Pembentukan yang dialami oleh Musa adalah menghadapi mentalitas budak bangsa yang sudah mandarah daging di bangsa Israel. Sebagai pemimpin Musa harus membawa pola pikir bangsa dengan mentalitas budak menjadi bangsa yang merdeka. ${ }^{48}$ Upaya inovasi yang dilakukan dalam kepemimpinan Musa adalah dengan mengangkat hakim-hakim yang memimpin kelompok-kelompok kecil (Kel.18:21). Inovasi ini tidak serta merta menghentikan Musa sebagai pemimpin, tetapi meringankan tugas kepemimpinan Musa. Inovasi kepemimpinan yang dilakukan akhirnya melahirkan prinsip kepemimpinan yang memberdayakan.

\section{Suksesi kepemimpinan}

Nasihat Yitro kepada Musa untuk mengajarkan ketetapan-ketetapan, keputusankeputusan, menunjukkan jalan yang harus dilalui serta pekerjaan yang harus dilakukan (Kek.18:20) oleh pemimpin-pemimpin kelompok kecil mengajarkan bahwa kepemimpinan butuh suksesi. Selaras dengan pernyataan yang berkata kesuksesan tanpa suksesi sama dengan dengan sebuah kegagalan. ${ }^{49}$ Sukses dalam kepemimpinan yang terjadi akan menjadi kegagalan jika tanpa ada suksesi. Dikaji dalam kasus Musa, jika tanpa pemimpin-pemimpin kelompok kecil maka kesuksesan kepemimpinan Musa hanya berhenti di masa pemerintahan Musa. Pemimpin-pemimpin kelompok kecil yang dilatih dan dimuridakan mampu membuat sukses yang terjadi dalam kepemimpinan Musa masih bisa berlangsung hingga ke pemerintahan selanjutnya. Partisipasi aktif yang dilakukan oleh masing-masing pemimpin kelompok kecil dalam mengembangkan kepemimpinan menjadi fondasi yang kuat untuk konsep pemberdayaan ${ }^{50}$ sehingga suksesi kepemimpinan dapat berjalan dengan baik.

\footnotetext{
${ }^{47}$ Boestam, Smart Christian Leadership.

${ }^{48}$ Ibid.

49 Ibid.

${ }^{50}$ Ulum, Perilaku Organisasi Menuju Orientasi Pemberdayaan.
} 


\section{KESIMPULAN}

Jika kepemimpinan hanya dikerjakan seorang diri atau yang lebih parah hanya berpusat pada pribadi pemimpin maka dampak kepemimpinan tersebut menjadi tidak efektif. Upaya yang dilakukan untuk mencapai kepemimpinan yang efektif adalah dengan mengembangkan prinsip kepemimpinan yang memberdayakan. Kepemimpinan yang memberdayakan merupakan kepemimpinan yang tidak berpusat pada diri sendiri. Fokus kepemimpinan memberdayakan adalah membantu individu yang dipimpin untuk mencapai tahap tertentu yang lebih baik serta mengusahakan sehingga menjadi pribadi yang berdaya. Prinsip yang dikembangkan dapat berupa mendelegasikan kepemimpinan, meningkatkan tanggung jawab, kapasitas, kemandirian serta mau belajar dan diajar. Dengan demikian, kepemimpinan tersebut dapat membawa pengaruh yang lebih besar dan menciptakan individu yang berdaya, tidak bergantung pada situasi ataupun organisasi tertentu. Prinsip kepemimpinan yang memberdayakan menjadi hal yang urgen mengingat situasi kepemimpinan di bangsa Indonesia juga mengalami penyimpangan kea rah mementingkan diri sendiri, bahkan gereja juga sudah menjadi sasaran empuk bagi orang-orang yang haus jabatan. Jawaban yang tepat untuk menciptakan pemimpin yang benar untuk generasi selanjutnya, melanjutkan kepemimpinan serta menciptakan suksesi kepemimpinan yang berdasarkan ketetapanketetapan, keputusan-keputusan, jalan yang harus dilalui serta pekerjaan yang harus dilakukan seturut kehendak Yesus Kristus sebagai kepala gereja yang menjadi pemimpin kita adalah dengan mewujudkan kepememimpinan yang memberdayakan. Pada hakikatnya kepemimpinan sukses jika ada suksesi kepemimpinan yang diwujudkan melalui memberdayakan orang lain dengan cara membantunya mengenal dan hidup sesuai kehendak Tuhan Yesus Kristus sebagai pemimpin.

\section{DAFTAR PUSTAKA}

Adair, John. Cara Menumbuhkan Pemimpin. Gramedia Pustaka Utama, 2007.

Ancok, Djamaludin. Psikologi Kepemimpinan Dan Inovasi. Jakarta: Gelora Aksara Pratama, 2012.

ANGGRAENI, LINTANG. “GEREJA KRISTEN JAWA PURWOREJO MENJADI GEREJA INTERGENERASIONAL.” UKDW, 2020.

Boa, Kenneth, Sid Buzzell, and Bill Perkins. Kepemimpinan Ilahi Dalam Rupa Insani. 
Jakarta: Yayasan Komunikasi Bina Kasih, 2013.

Boestam, Pudijiarto. Smart Christian Leadership. Yogyakarta: ANDI OFFSET, 2013.

Browning, W.R.F. Kamus Alkitab. Jakarta: BPK Gunung Mulia, 2009.

Carnegie, Dale. Leadership Mastery. 9th ed. Jakarta, 2019.

Covey, Stephen R. The 7 Habits of Highly Effective People. Edited by Lyndon Saputra.

Tangerang Selatan: Binarupa Aksara, n.d.

Gidion, Gidion. "EFEKTIFITAS KEPEMIMPINAN YANG MEMBERDAYAKAN DALAM MENINGKATKAN PERTUMBUHAN GEREJA DI GEREJA JEMAAT KRISTEN INDONESIA MARANATHA UNGARAN.” Shift Key: Jurnal Teologi dan Pelayanan 8, no. 1 (2018).

Hamzah, Amir. Metode Penelitian Kepustakaan Library Research. Malang: Literasi Nusantara, 2020.

Hosea, Amos. "FENOMENA KELOMPOK SEL (CELL GROUP) DALAM GEREJA LOKAL.” Diegesis: Jurnal Teologi 3, no. 2 (2018): 1-11.

Indradin, Indradin, and Irawan Irawan. Strategi Dan Perubahan Sosial. Yogyakarta: CV BUDI UTAMA, 2016.

Irwan, Abdurrohman, ed. Membangun Dan Memberdayakan Potensi Di Masyarakat Di Kala Pandemi. Bandung: LP2M UIN Sunan Gunung Djati Bandung, 2021.

Katarina, K, and Krido Siswanto. "Keteladanan Kepemimpinan Yesus Dan Implikasinya Bagi Kepemimpinan Gereja Pada Masa Kini.” Evangelikal: Jurnal Teologi Injili dan Pembinaan Warga Jemaat 2, no. 2 (2018): 87-98.

Komisi Pemberantasan Korupsi. "Statistik TPK Berdasarkan Profesi/Jabatan." Kpk.Go.Id. Last modified 2021. https://www.kpk.go.id/id/statistik/penindakan/tpkberdasarkan-profesi-jabatan.

Kompas, Kompas. "Persaingan Produk Di Pasar Global." Kementerian Perindudtrian Republik Indonesia. Last modified 2020. Accessed April 5, 2021. https://kemenperin.go.id/artikel/21400/Persaingan-Produk-di-Pasar-Global.

KPK. "Komisi Pemberantasan Korupsi." Kpk.Go.Id. Last modified 2021. Accessed April 5, 2021. https://www.kpk.go/id/statistik/penindakan/109-statistik.

Kusradi, Sri Wahyuni. "Pengenalan Akan Nama Allah Sebagai Peneguhan Iman Dalam Masa Kesesakan.” SCRIPTA: Jurnal Teologi dan Pelayanan Kontekstual 6, no. 2 (2018): 184-204. 
Lidya, Febby. "Peran Pemimpin Dalam Peningkatan Kapasitas Kelompok Berbasis Community Based Tourism" (2018).

Maxwell, John C. The 5 Level Leadership. Surabaya: MIC, 2017.

Minsih, Minsih, Rusnilawati Rusnilawati, and Imam Mujahid. "Kepemimpinan Kepala Sekolah Dalam Membangun Sekolah Berkualitas Di Sekolah Dasar." Profesi Pendidikan Dasar 6, no. 1 (2019): 29-40.

Murniawaty, Indri, and Wisudani Rahmaningtyas. "Kesiapan Mahasiswa Jurusan Pendidikan Adminstrasi Perkantoran Dalam Kompetisi Pasar Kerja Di Era Mea." PROMOSI: Jurnal Program Studi Pendidikan Ekonomi 5, no. 1 (2017).

Nasution, Mahyuddin K M. "Penelaahan Literatur." Teknik Penulisan Karya Ilmiah 3 (2017).

Octaria, Dina, Putri Fitriasari, and Novita Sari. "Blended Learning Dengan Macromedia Flash Untuk Melatih Kemandirian Belajar Mahasiswa.” Jurnal Elemen 6, no. 1 (2020): 25-38.

Paterson, Robert M. Tafsiran Alkitab Kitab Keluaran. Jakarta: BPK Gunung Mulia, 2006.

Prabowo, Wisnu. "Peran Elkana Dan Hana Terhadap Masa Kecil Samuel: Tahap Awal Mencetak Pemimpin Kristen." EDULEAD: Journal of Christian Education and Leadership 1, no. 2 (December 10, 2020): 162-179. http://stak-pesat.ac.id/ejournal/index.php/edulead/article/view/39.

Risanti, Ni Made Nita. "Penerapan Metode Pemberian Tugas Berbantuan Media Konkrit Melalui Kegiatan Finger Painting Untuk Meningkatkan Perkembangan Sosial Emosional.” Jurnal Pendidikan Anak Usia Dini Undiksha 1, no. 1 (2013).

Sisca, Hengki M.P Simarmata, Ernest G.B Purba, Indah Kusuma Dewi, Marto S Fajrilah, Andriasan Sudarso, and Eko Sudarmanto. Manajemen Inovasi. Edited by Janner Simarmata. Yayasan Kita Menulis, 2021.

Siswanto, Rendyka Dio, and Djambur Hamid. "Pengaruh Gaya Kepemimpinan Terhadap Kinerja Karyawan (Studi Pada Karyawan Divisi Human Resources Management Compensation and Benefits PT Freeport Indonesia)." Jurnal Administrasi Bisnis 42, no. 1 (2017): 189-198.

Suharto, Edi. Membangun Masyarakat Memberdayakan Rakyat Kajian Strategis Pembangunan Kesejahteraan Sosial Dan Pekerjaan Sosial. Bandung: PT Refika 
Aditama, 2009.

Suryo, Herning. "Pemberdayaan Masyarakat Dalam Pengembangan Kemandirian Masyarakat." Transformasi 1, no. 29 (2017).

Sya'roni, Deden A Wahab, and Janivita J Sudirham. "Kreativitas Dan Inovasi Penentu Kompetensi Pelaku Usaha Kecil.” Jurnal Manajemen Teknologi 11, no. 01 (2012): $1-17$.

Tabrani, Ahmad. "PENGARUH KEPEMIMPINAN DAN MENTORING TERHADAP MOTIVASI DALAM MELAYANI.” EDULEAD: Journal of Christian Education and Leadership 1, no. 1 (June 9, 2020): 77-91. http://stak-pesat.ac.id/ejournal/index.php/edulead/article/view/23.

Ulum, M.Chazienul. Perilaku Organisasi Menuju Orientasi Pemberdayaan. Malang: UB Press, 2016.

Widjaja, Imron. "PERKEMBANGAN KOMSEL PELAJAR DALAM PERTUMBUHAN ROHANI JEMAAT GBI GRAHA PENA JAKARTA." The Way Jurnal Teologi dan Kependidikan 5, no. 2 (2019): 88-100.

Wijaya, Elkana Chrisna. "Prinsip Kepemimpinan Yang Efektif Menurut Kitab Keluaran 18:13-27." Harvester: Jurnal Teologi dan Kepemimpinan Kristen 6, no. 3 (2017): $120-140$.

Wijaya, Hengki. "Keunggulan Integritas Generasi Muda Dalam Mewujudkan Kepemimpinan Rohani Yang Bertanggungjawab." Online] https://www. researchgate. net/profile/Hengki_Wijaya3 (2015).

Zaluchu, Sonny. "Respons Tests of Leadership Menurut Teori Frank Damazio Pada Mahasiswa Pascasarjana Jurusan Kepemimpinan Kristen STT Harvest Semarang.” Jurnal Jaffray 16, no. 2 (2018): 145.

Zaluchu, Sonny Eli. "Strategi Penelitian Kualitatif Dan Kuantitatif Di Dalam Penelitian Agama.” Evangelikal: Jurnal Teologi Injili dan Pembinaan Warga Jemaat 4, no. 1 (January 31 , 2020):

28. https://journal.sttsimpson.ac.id/index.php/EJTI/article/view/167. 